\title{
The emerging role of a food system planner: Integrating food considerations into planning
}

Tammara Soma $^{\mathrm{a}}$ and Sarah Wakefield ${ }^{\mathrm{b}}$

Submitted 22 July 2010 / Revised 17 December 2010 and 25 July 2011 / Accepted 27 July 2011 / Published online 13 October 2011

Citation: Soma, T., \& Wakefield, S. (2011). The emerging role of a food system planner: Integrating food considerations

into planning. Journal of Agriculture, Food Systems, and Community Development, 2(1), 53-64.

http://dx.doi.org/10.5304/jafscd.2011.021.006

Copyright (C) 2011 by New Leaf Associates, Inc.

\begin{abstract}
Recently, the planning profession in North America has begun to recognize the importance of integrating food considerations into planning. However, the field of food system planning is still in its infancy, and its proponents seek a more thorough understanding of the applied role of planning practitioners in this emerging field. This exploratory investigation included interviews with a small sample of self-identified "food system planners" in Canada and the United States whose work is quietly nurturing this emerging subfield in the planning profession. Based on the views of this sample of planners, we offer several considerations on how the professional planning establishment can enhance the ability of planners to contribute to the

a Corresponding author: 34 Eglinton Avenue West, Suite 337, Toronto, Ontario M4R2H6 Canada; +1-647-703-4373; tammara.soma@gmail.com

b Department of Geography and Programme in Planning, 5th Floor Sidney Smith Hall, University of Toronto, 100 St. George St., Toronto, M5S 3X3 Canada; +1-416-978-3653; sarah.wakefield@,utoronto.ca
\end{abstract}

development of holistic, sustainable, and equitable food systems. The lessons learned here may be applicable to other fields and disciplines where food system work is an emerging focus.

\section{Keywords}

food security, food system education, food system planner, food system planning

\section{Introduction}

Interest in food issues has increased in recent years in both the popular press (e.g., Kingsolver, 2007; Pollan, 2006, 2008, 2009; Schlosser, 2001) and planning circles (American Planning Association [APA], 2007; OPPI, 2009; Raja, Born, \& Kozlowski Russel, 2008). Recent work by Kaufman (2009), Raja et al. (2008), and Pothukuchi and Kaufman (2000) outlines possible roles for planning in ensuring that communities have consistent and sustainable access to food.

This paper attempts to contribute to emerging discussions about the role of food in planning (and vice versa) by investigating the actual on-the- 
ground work carried out by a small sample of North American planners specializing in food system planning, as well as other planners working on food-related issues. Drawing on in-depth interviews with planners in Canada and the United States, the paper focuses on identifying the need for food systems expertise within planning, and the skills required for food system planning. The paper concludes with strategies that the planning profession and academe should consider in the context of preparing planners for the growing opportunities in the food system arena. While the paper focuses on experiences within the planning profession, other practitioners who work on food system issues may find some lessons in the experiences of these "food pioneers," and might consider exploring the relevance of our findings for other areas of practice.

\section{Literature Review}

\section{Background: Our Food System}

Planning for food security in cities actually has a long history: As architect and author Carolyn Steel suggests, "without farmers and farming, cities would not exist" (Steel, 2008, p. 7). For millennia, cities evolved around and in accordance with food distribution routes (Steel, 2008). Prior to the industrialized age, growing food was part of city life, and during particular periods (e.g., the World War II years), urban agriculture has been promoted.

Depending on the prevailing wisdom of the day, food cultivation in and for cities has been either encouraged or discouraged by urban planners. Indeed, modern planning approaches have often discouraged urban food production (Nasr, MacRae, \& Kuhns, 2010). Access to urban and peri-urban land for agriculture has been lost as a result of agricultural restructuring and urban development pressures (Magdoff, Buttel, \& Foster, 2000; Redwood, 2009). Moreover, planners often place grocery stores under the more general rubric of "commercial retail development," leaving this critical land use open to market forces rather than treating as it as an important piece of civic infrastructure that deserves concentrated attention. As a result, in most North American cities today, many new grocery stores, along with big box outlets, are built more than 546 yards (500 meters) away from residential land, which makes them accessible only by cars (Larsen \& Gilliland, 2008). The phenomenon of food deserts - areas where a community lacks access to healthful and nutritious food - in cities around North America is connected to planning decisions (Larsen \& Gilliland, 2008).

In addition, modern industrial agriculture, which has been the dominant food regime led by the global North (Friedmann, 2005), has focused on producing commodity crops for international trade rather than food production for local consumption (Magdoff et al., 2000). Urban consumers have become distanced from the sources of their food, both geographically and psychologically (Wittman, 2009). Much of the food we eat travels through long, energy-intensive commodity chains before arriving, anonymous, on the shelves of local supermarkets (Watts \& Goodman, 1997). The abundance and diversity of food available in most grocery stores could lead observers to believe that access to food in urban centers is not a problem. However, our food security is threatened by an unsustainable food supply system (e.g., Bunce \& Maurer, 2005; Forkes, 2007; Morison, Baker, Mullineaux, \& Davies, 2008; Xuereb, 2005) that critics suggest pays more attention to profitability than it does to equity, the environment, and health (Lang \& Heasman, 2004; Nestle, 2002; Power, 1999). Chronic crises in farming and fisheries continue to threaten the livelihoods of food producers (Qualman \& Wiebe, 2002), while the high cost of production is leading many to abandon farming altogether.

It has been estimated by retailers that there are only about three days worth of fresh food in major cities at any given time, leaving them vulnerable to emergencies that could close supply lines, such as disease epidemics, natural disasters, trade embargos, etc. (Campsie, 2008). A broad base of local production could help fill food supply gaps in times of disruption and scarcity (Trinh et al., 2003). In addition, access to food is not that straightforward for the increasing number of Canadians and Americans living in poverty who cannot afford 
food after other costs of living have been paid (Food Banks Canada, 2010; U.S. Census Bureau, 2010). In New York City alone, $40 \%$ of residents (more than 3.3 million New Yorkers) experienced difficulty affording food in 2009, an increase of 60\% since 2003 (Food Bank for New York City, 2009). A food system that better meets the needs of all residents is required to ensure the entire population can access food with dignity.

A healthy and sustainable food system, according to the American Public Health Association, is one that:

provides healthy food to meet current food needs while maintaining healthy ecosystems that can also provide food for generations to come with minimal negative impact to the environment. A sustainable food system also encourages local production and distribution infrastructures and makes nutritious food available, accessible, and affordable to all. Further, it is humane and just, protecting farmers and other workers, consumers, and communities. (APHA, 2007, para. 4)

Moving toward a more sustainable food system will require addressing the problems in the food system identified above in a comprehensive and systematic way.

\section{Planning the Food System}

There is a significant opportunity for planners to contribute to more sustainable food systems and healthier communities. Planning as an occupation aims to improve the welfare and health of people and communities through the logical arrangement of land, resources and facilities (CIP, 2009; American Planning Association [APA], 2009a). Moreover, Hodgson (2009) argues that it is impossible to have healthy communities without healthy food systems. Pothukuchi and Kaufmann (2000) have defined the food system as the "chain of activities connecting food production, processing, distribution, consumption, and waste management, as well as all of the associated regulatory institutions and activities" (p. 113). It is thus not merely a unidirectional "farm-to-fork" system, but rather a circular system that includes the reintegration of waste into food production.

It is easy to see areas of interface between traditional subfields of planning (e.g., rural, urban, landuse, transportation, environmental, economic development, etc.) and food systems. However, none of these existing subfields fully incorporates food system planning: for example, even agricultural land use planners generally fall under the umbrella of rural planning, which focuses almost exclusively on rural areas and does not address the whole food system per se (see for example the Ontario Ministry of Agriculture, Food and Rural Affairs' roles for agricultural land use planning staff (OMAFRA, 2010)).

Kaufman (2009) suggests that food issues of particular relevance to planning include:

- food deserts, where access to affordable quality food is difficult;

- food traveling long distances, resulting in excessive use of fossil fuel energy; and

- environmental and social costs of food production, including processing, storage, distribution and waste.

In addition, issues related to preserving agricultural land and sustaining food-related livelihoods in both urban and rural settings are of importance to planners (Churchyard, 2010).

Planners increasingly are recognizing the importance of food systems in their practice, and more specifically for the communities they serve. In 2005 , a session on food system planning was held for the first time in the APA's history. An APA white paper on the importance of planning's role in the food system was the impetus for the APA's Policy Guide on Community and Regional Food Planning (APA, 2007), which recognizes that the food system has implications for health, the economy, ecological systems, social equity, and culture. In a recent survey conducted by Raja et al. (2008), 90\% of the 192 APA members who responded felt that 
farmland preservation should be a significant or top priority for the planning profession. In Canada, the Ontario Professional Planners Institute (OPPI) conducted a survey wherein close to $50 \%$ of members surveyed felt that planners should have a significant involvement in community and regional food system issues, while $10 \%$ felt that it should be a top priority (Caldwell, 2010). In October 2010, this same organization organized a symposium solely devoted to food planning entitled "Healthy Communities and Planning for Food" (OPPI, 2010).

The increasing interest in food among planners is slowly making its way into the planning curriculum as well. According to Hammer (2004), $60 \%$ of the 68 U.S. programs accredited by the Association of Collegiate Schools of Planning did not offer any food systems-related courses in 2004. However, Chrisinger (2009) reported an increase in demand for food-related courses in planning schools, and noted that students were also becoming involved in more food-related work such as farm apprenticeships and school gardens.

With the growing awareness of the importance of food considerations in shaping healthier communities, there are increasing opportunities for planners to be involved in food system planning. There is growing momentum in food advocacy and a stronger awareness of food-related issues in the public sector. For example, there has been a strong demand for backyard chickens in cities across North America, and city officials are taking note of this controversial planning and public health issue (MacDonald, 2009; Peat, 2010). Meanwhile, in the United States, many cities have started to consider producing regional food planning documents or conducting studies for food planning (see, for example, A Guide to Local Food System Planning for Scott County, Minnesota (Aitchison, 2009), or Fertile Ground: Food Systems Planning for Madison/Dane County (University of Wisconsin-Madison Department of Urban and Regional Planning, 1997)).To date, however, we know of no prior study (quantitative or qualitative) in the planning literature that has included in-depth interviews with planners currently active in food systems work. In this explora- tory study, we have documented some of the barriers that planners face when conducting work related to food system planning, and identified a few key strategies that will help the planning community value this increasingly important work.

\section{Methods}

Informal, semistructured interviews were conducted with 12 planners from Canada and the United States. A call for participation in this study was conducted through two of the main food and planning listservs, Planning for Agriculture and Food Network (PAFN) in Canada, and Food and Planning for the United States. ${ }^{1}$ These listservs were seen as likely sources to contact planners interested in food. As the universe of planners who were selfdescribed "food system planners" was small and no list of planners actively engaged in food systems was known to exist, we used a snowball sampling approach. Of the 12 planners interviewed, 11 identified themselves very broadly as "food system planners" with various degrees of involvement with food and agriculture-related matters. It is important to note that only two of the 12 planners had the actual job title of "food system planner." Some of the planners interviewed have been pioneers in the field of food systems planning, while others had just started to include food considerations in their day-to-day work.

We used a semistructured interview guide with a uniform set of core questions (see table 1). In addition to this core interview structure, interviewees were given ample freedom to explore ideas and share opinions on various issues. All interviews were taped and transcribed, and interview transcripts were reviewed for key themes based on the goals of the research. Wherever possible, verbatim quotes are used to illuminate key themes.

\footnotetext{
1 These listservs can be accessed by following the instructions available at http://www.agf.gov.bc.ca/ resmgmt/sf/plan food/network.pdf (for the PAFN listserv) and http://mailman2.u.washington.edu/ mailman/listinfo/foodplanning (for the Food and Planning listserv).
} 


\section{Table 1. Interview Core Questions}

1. What is your title and how did your role evolve to include food systems considerations (or has it always been a part of your role)?

2. What are specific land use and food-related issues you have dealt with?

3. In your opinion, what are the benefits or drawbacks (if any) of specifically categorizing oneself as a food system planner?

4. What are the challenges (if any) that you have encountered in planning for a sustainable food system?

5. What is your perspective on whether or not there are gaps in the planning field when it comes to understanding the importance of food and agriculture considerations?

6. What do you see as the role of planners in food systems work?

7. What are specific skills that you have as a planner that you feel are beneficial in the work toward a sustainable food system?

8. How can we improve opportunities to integrate food considerations in municipal or regional planning?

\section{Results}

\section{Background Characteristics of the Interviewees}

Table 2 summarizes the backgrounds of the interviewees. The interviewees included six Canadians and six Americans. This was purely coincidental. Since we believe there are not enough cases to make any significant generalizations, no distinction other than their nationality is made in this analysis. Twice as many females than males participated in

Table 2. Summary of Interviewee Backgrounds $(\mathrm{N}=12)$

\begin{tabular}{ll}
\hline Educational Background & \\
\hline Degree in planning & 10 \\
\hline Degree in field other than planning & 2 \\
\hline Gender & 8 \\
\hline Female & 4 \\
\hline Male & 5 \\
\hline Sector of Occupation & 3 \\
\hline Public & 2 \\
\hline Private & 2 \\
\hline Academic & 6 \\
\hline Nonprofit & 6 \\
\hline Country
\end{tabular}

the study. The interviewees were distributed unevenly across four occupational sectors, including private consulting firms, public planning departments, academic programs, and nonprofit organizations.

All but two of the planners interviewed have degrees in planning. However, the two participants without planning degrees have planning experience working for a private firm and a municipal planning department. All but one of the planners identified with the broad category of food system planner, as they were working or have worked on food-related matters. One planner did not consider herself a food system planner, but we included her in the study because she had seen an increasing demand for knowledge of the food system.

\section{Food Systems as a Planning Priority}

All the planners interviewed believed that food system planning is of increasing interest, but that it is not at the top of the list for most planning priorities due to structural constraints within planning departments. Some planners noted that "food system planning" was not well understood or institutionalized. The role of a food system planner could be characterized at the moment by abject "vagueness." As one planner put it,

I definitely call myself a food system planner, but it is kind of a made-up term, because it 
doesn't really exist out there as part of the professional world yet.

Another planner who does not actually have a formal planning title said,

My title is vague. We have a food policy program and I manage that...so I consider myself a food system planner by default.

Meanwhile, another planner was slightly more optimistic about people understanding her title and role as a food system planner:

I do think the occupation is becoming recognized, but in terms of synchronizing the language, I think that is the challenging part.

But the vagaries of titles are just a symptom of much larger structural barriers in defining and expanding food system planning. One Canadian planner who works in a private firm lamented the bureaucracy hindering support for food planning:

The limits aren't the idea, the limits aren't the technology, and the limits aren't how creative we can be.... The limits are things like needing to meet density targets, dealing with "scarce land resources."...We talk a lot about developing complete communities that can sustain themselves, we use the word sustainable in every sentence — it's totally lost its meaning as far as I'm concerned.

The quote above illustrates the resistance by municipalities and city bureaucracies with respect to supporting innovative programs and policies related to food. Put simply, planning for food is not a priority in most municipalities in North America. However, the interviewees did note that some food issues are coming onto the radar screens of planners - for example, one interviewee noted that farmland preservation is an increasingly important issue due to concerns over sprawl and rapid urban growth. However, other food issues remain off the radar:
Truthfully, if we look at it fairly generally across the country, there are many priorities. Strangely enough, farmland preservation might be ranked more highly than what we think, but food would not necessarily be that highly ranked, so in some ways, we are dealing with the traditional sets of issues of which the protection of farmland is one but the protection of farmers and farming livelihoods is not so highly rated.

This quote reminds us that attending to one aspect of food planning (e.g., farmland preservation) without addressing others (e.g., adequate farm incomes, availability of local food distribution channels) in a holistic manner can fail to solve problems. For example, the same zoning laws and policies that protect or preserve farmland in some cases may restrict farmers' ability to increase their incomes by prohibiting farmers from selling their own value-added products on their farms. This restricts farmers' livelihoods and could compromise their ability to continue farming.

Meanwhile, as another interviewee noted, the general public seems to be moving ahead of the planning profession in relation to food issues:

It's actually very interesting how knowledgeable the public is about food planning and how obvious the lack of food system planners within the city, and within the typical consulting firm, is.

According to this respondent, the planning profession clearly has some catching up to do to be able to address adequately these issues of public concern.

\section{Topical and Technical Expertise Required} To Be a Food System Planner

We discovered in our interviews that planners' experience with farms and agricultural systems were seen as important, especially in terms of perceived credibility. A planner with a background in agriculture stressed the importance of a practical knowledge of food growing: 
I think it is very important that planners have an understanding of agriculture. It is difficult to advocate for change if you don't truly understand the existing system....We want to make sure that we can speak with conviction and we want to speak from a perspective that is not naïve....We need to have a handle on our role but also a good handle of what agriculture is all about, the challenges farmers face, the dilemmas and difficulties of making a living, while at the same time speaking and looking forward to a new system approach.

Planners specializing in food often interact with farmers. In this planner's case, her knowledge of growing food enabled her to communicate with stakeholders:

I had to facilitate a meeting with farmers and they looked at me like "who is this city woman and what does she know about farming." And it is true, I am learning about farming and I am not a farmer...so on one hand I know quite a bit about farming, but on the other hand I'm not a farmer; but at least the knowledge that I had gave me the confidence to navigate through that experience.

The interviewees emphasized the need for both technical expertise as well as so-called "soft skills" in food system planning activities. Table 3 summarizes the various examples of skills needed in food planning that emerged in the interviews. Interviewees identified four broad categories of skills that would be beneficial in food systems planning. While specific, technical knowledge in both agriculture and planning were seen as essential, other, more transferrable skills — such as approaching problems holistically, having interpersonal communication and facilitation skills, and research

\section{Table 3. Skills and Expertise Needed for Competent Food System Planning}

\begin{tabular}{|c|c|}
\hline Skill Set or Area of Expertise & Examples of Planning Activities Requiring These Skills \\
\hline $\begin{array}{l}\text { Technical knowledge and skills: } \\
\text { - } \quad \text { Data collection and statistical analysis and } \\
\text { presentation } \\
\text { - } \quad \text { Mapping and GIS } \\
\text { - Knowledge of agriculture } \\
\text { - Knowledge of planning (regulations, best } \\
\text { practices, etc.) } \\
\text { - Knowledge of the food system, including but } \\
\text { not limited to: food processing industry, } \\
\text { wholesale and retail distribution, community } \\
\text { gardening, community centers, composting }\end{array}$ & $\begin{array}{l}\text { - Identifying and amending planning and land use regulations } \\
\text { that hinder local food systems and/or food access (e.g., } \\
\text { protecting prime agricultural land, reducing food deserts, and } \\
\text { facilitating development of community gardens and farmers' } \\
\text { markets) } \\
\text { - Identifying suitable land for urban agriculture } \\
\text { - Conducting Community Food Assessments } \\
\text { - Reviewing land use and development proposals and } \\
\text { applications } \\
\text { - Creating incentives or plans that can be used to encourage the } \\
\text { development of a particular land use supportive of food growing }\end{array}$ \\
\hline $\begin{array}{l}\text { Oral communications: } \\
\text { - Public speaking } \\
\text { - Group or meeting facilitation } \\
\text { - Community engagement } \\
\text { - Negotiation } \\
\text { - Conflict resolution }\end{array}$ & $\begin{array}{l}\text { - Public engagement activities with farmers, urban communities, } \\
\text { food producers and retailers, land developers, other policy- } \\
\text { makers, etc. } \\
\text { - Work on multistakeholder committees (e.g., Food Policy } \\
\text { Councils) } \\
\text { - Collaborations with other departments (public health, economic } \\
\text { development, etc.) }\end{array}$ \\
\hline $\begin{array}{l}\text { "Big picture" holistic systems approach } \\
\text { (recognizing interconnectivity) }\end{array}$ & $\begin{array}{l}\text { - Planning to reduce obesity } \\
\text { - Planning for agritourism } \\
\text { - } \text { Food-related local economic development } \\
\text { - Risk management and security planning }\end{array}$ \\
\hline Research and writing skills & $\begin{array}{l}\text { - Policy research (e.g., environmental scans, identifying best } \\
\text { practices) } \\
\text { - Policy development (e.g., drafting bylaws and policy statements } \\
\text { on such diverse issues as community gardens, farmers' } \\
\text { markets, agricultural land use, animal control, etc.; developing } \\
\text { food charters) }\end{array}$ \\
\hline
\end{tabular}


writing - were also seen as important to successful food planning.

Some of the participants also suggested that the food system planner needs to not only be a technical expert, but also, given the appropriate context, a teacher, advocate, liaison, capacity-builder, and facilitator. Emphasizing this point, one interviewee noted that a key component of a food system planner's role is "to bring other planners up to speed on what planning for food looks like so that they can bring it to their practice."

\section{Food Systems in Planning Education}

All the planners interviewed felt that general planning education should include a greater emphasis on food systems. Interestingly, only one out of the 10 planners with a formal planning education was able to take a food-related course during their university studies. Food system planning is generally not a formal part of the curriculum for most academic planning programs, although this is beginning to change. It is no wonder that, while the planners interviewed possessed many of the skills required to successfully address food system activities, they have adapted by taking a "learn as you go" approach. As one planner put it,

I come from an agriculture background. I have done a little bit of planning in my masters degree...but I am not a member of the Canadian Planning Institute. So, I've always been interested in agriculture and food systems, but I haven't had the opportunity to do any work directly in food system planning before, so I guess I'm learning by doing.

The issue of how best to train planners in food systems emerged as an interesting question, with two competing ideas: specialization (in which one's training would largely focus on food systems) and integration (having food systems integrated into the general planning education). The interviewees presented strengths and drawbacks of both approaches. For example, a regional planner who commented on the lack of food systems planning expertise in his department suggested that a specialization would be useful:
In our department, we have quite a few planners and a lot of our planners specialize in different things, housing, transportation, transit, agriculture, but we don't have somebody who is specialized as a food system planner and in a department of that size it might be useful to have someone like that specifically devoted to that kind of work.

Echoing this view, a planner in a private firm suggested:

In terms of being on the leading edge, yes, we do have a real opportunity... but you need a specialist on the team to push the idea, and I think what you would find is that there aren't that many people who are able to work as food system planners.

The opposing view was expressed by another planner who is concerned that making food system planning a specialization could create more "silos" in the profession:

I am certainly of the impression that food systems planning needs to be more integrated into other disciplines. It can't be an isolated expertise because the way you move forward is actually embedding food planning into other activities.

This sentiment was shared by a planner who is also an academic, who said,

It is important to have courses, tasks, interests and whatnot that focus solely on food so that you can really go deeply into those issues, but it is equally important for planners to understand that the food system is a system.... Planners need to understand this system as one of the systems that they are responsible for and that they need to be cognizant of and conversant in it just like housing, economic development, transportation or anything else.

With respect to the issue of specialization versus integration, one planner suggests is not an "either or" position, but a "both and" position, maintain- 
ing that it is possible to produce specialists in food system planning while at the same time integrating food considerations into other planning subfields. But the reverse is also true: it should be possible to be a planning generalist, or a specialist in some other recognized planning subfield such as transportation, housing, land use, or economic development, and still have some training in food systems.

\section{Emerging Themes and Next Steps}

This was an exploratory study, and as such it is neither appropriate to make sweeping generalizations about planners or the planning profession, nor to offer very specific recommendations. However, we do believe this study highlighted some critical emerging themes as the professional planning community begins to recognize the role of food system planning, and we offer the following three considerations:

\section{Food system planners desire and deserve greater recogni- tion from the professional planning establishment.}

First and foremost, the time seems to have come for food system planning to be recognized as a legitimate planning subfield. As we described in our introduction, the American Planning

Association has taken dramatic steps in the last five years to elevate the status of food systems planning in the profession. As of this writing, the APA has received funding from the Robert Wood Johnson Foundation for research on reducing food access disparities among children, adolescents and adults (APA, 2009b). Furthermore, about 100 members of the APA have established a Food Interest Group that provides some resources and initiatives for planners. We agree with planners who are calling for the APA to expedite creating a Food Systems Planning Division, which has a higher level of recognition in the association and can provide support for food system planners and the growing field of food systems planning on a much larger scale. The creation of an APA division would provide tools and resources such as newsletters and special publications, as well as offer the ability to organize conferences and workshops on special topics of interest to the division. As a division, these planners would be in a position to pro- vide critical social networking opportunities and take leadership in the development of the food systems planning subfield. The Canadian Institute of Planners should also take a proactive approach similar to the APA and acknowledge the food system as part of the planner's responsibility in its mandate.

\section{Food system planners and related professionals should consider establishing a more formal community of practice that includes professional development training in food systems planning.}

In this time of fiscal austerity, many communities may surmise that it is not practical to hire a food system planner or specialist. Communities that do not choose to hire a planner with a food system specialty might consider sending one of their current planners to a professional development program on food systems. We therefore recommend that a professional development certificate in food systems planning program be established. This could include amassing credits by participating in distance learning, conference workshops, and/or special training opportunities at national conferences, as well as traditional classroom opportunities. However professional development moves forward, there is little doubt that many planners will be interested in "getting up to speed" on food system planning.

\section{Consider expanding traditional urban and regional planning degree programs.}

Just as professional organizations are warming up to food system planning as a legitimate planning endeavor, traditional planning education is also showing signs of doing the same (Chrisinger, 2009). We recommend that this trend continue so that planners are able to develop some level of familiarity with food issues during their program of study. This can include greater engagement with food issues through "core" or required courses, as well as standalone electives on food planning. While this paper focuses on the planning discipline, similar trends are likely occurring in other fields as well (e.g., geography, architecture, rural sociology, and public health). These academic fields will address food system issues through their specific disciplinary focus, however, and so should not be 
seen as adequately substituting for food systems training within planning programs. Corporations, foundations, and national agencies may be interested in supporting the development of the field of food systems planning, and we suggest that appropriate sources of funding be secured to support food research and curriculum development in planning programs.

In addition to the recommendations above, there is considerable room to enhance our understanding of food systems planning through further research. This exploratory investigation only scratched the surface. We believe there is considerably more to learn from planners about the state of food system planning, and we recommend that a larger quantitative study be conducted to gather details about specific tools, strategies, and approaches that planners are currently employing in their food systems work, as well as gaps they observe in training and education. Case studies in food system planning would follow naturally from this quantitative study and would help us to develop best practices. Other research could include an exhaustive inventory of current planning programs that offer food systems planning courses, as well as those offered by the allied fields of geography, sociology, community development, economics, and political science. Curriculum and syllabi could be gathered and made available to faculty and graduate teaching assistants to support work being done in this emerging field.

\section{Conclusion}

The small number of interviewees in the current study reflects the relatively small number of planners engaged in substantial food systems work. The interviewees generally continue to see validation and recognition for the work they are doing in food systems planning. They have become de facto food system planners or specialists because they agreed to take on the work when it was presented to them. With little support from their employers and their professional organizations, these intrepid pioneers are beginning to cultivate the nascent field of food systems planning. As communities continue to factor food production, processing, distribution, consumption, and waste recycling into the mainstream planning calculus, there will be grow- ing demand for planners with food system knowledge and expertise.

Planners have particular skill sets (e.g., the technical knowledge to deal with land use and zoning, spatial analysis and mapping, statistical analysis, and demographic projections) that can complement the skills and activities of other professionals who are currently working hard to address particular food systems issues (e.g., public health professionals, community development practitioners, and architects). Planners are already involved, in some way, with one or several components of the food system; for example, zoning bylaws and land use policies affect every component of the food system. With the rise of food-related activities ranging from urban agriculture initiatives, regional food policy, farmland preservation plans, to increased concerns in the community over the impact of the built environment on health (food deserts, for example), engaging planners who have a strong understanding and practical experience in food systems is needed to navigate the complexities of the food system and to deliver successful projects.

There are a plethora of social, economic, and environmental benefits embedded in planning for food, and ensuring healthy food systems is vital to both urban and rural communities. Applying professional planning expertise to the creation of food systems that are ecologically sustainable and more equitable is a worthwhile endeavor. The interviews with planners clearly demonstrate they have a critical role to play in creating sustainable food systems. They offer a wide array of specific technical knowledge, as well as leadership skills that assist in providing effective communication with neighborhoods, communities, cities, and regions that wish to plan for a more sustainable food future. In this paper we have identified some of the key issues and concerns of planners who are actively engaged in food system-related planning activities. While the focus here was on the planning profession, similar transitions are likely underway in other fields, and we hope that this paper will raise awareness of the importance of a holistic approach to planning food systems, both within and outside the planning profession. 


\section{References}

Aitchison, K. (2009). A guide to local food system planning for Scott County. Minnesota. Minneapolis: University of Minnesota.

American Planning Association (APA). (2007). Policy guide on community and regional food planning. Retrieved from http://www.planning.org/policy/guides/ adopted/food.htm

American Planning Association (APA). (2009a). What do planners do? Retrieved from http://www.planning. org/aboutplanning/whatisplanning.htm\#2

American Planning Association (APA). (2009b). Access to bealthy food starts with planning. Retrieved from http://www.planning.org/newsreleases/2009/ nov12.htm

American Public Health Association (APHA). (2007). Toward a sustainable bealthy food system (policy number 200712). Retrieved from http://www.apha.org/ advocacy/policy/policysearch/default.htm?id=1361

Bunce, M., \& Maurer, J. (2005). Prospects for agriculture in the Toronto region: The farmer perspective. Toronto: Neptis Studies on the Toronto Metropolitan Region.

Caldwell, W. (2010, October 28). The planner, food systems and food policy: An Ontario perspective. Presentation at the Ontario Professional Planners Institute Symposium, Guelph, Canada.

Campsie, P. (2008). Food connects us all: Sustainable local food in Southern Ontario. Toronto: Metcalf Foundation.

Canadian Institute of Planners (CIP). (2009). Planning Defined. Retrieved from http://www.cipicu.ca/ web/la/en/pa/3FC2AFA9F72245C4B8D2E70 9990D58C3/template.asp

Churchyard, A. (2010). Planning regional food systems: A guide for municipal planning and development in the Greater Golden Horseshoe. Guelph, Canada: Ontario Farmland Trust.

Chrisinger, B. (2009, Fall). Expanding the academic menu: Today's planning students have an appetite for food systems. The New Planner. Retrieved from http://www.planning.org/thenewplanner/

Food Banks Canada. (2010). Learn more about bunger in Canada. Retrieved from http://foodbankscanada. ca $/$ main2.cfm?id=10718629-B6A7-8AA06D9B9CE378DE06DA
Food Bank for New York City. (2009). NYC Hunger Experience 2009: A year in recession. Retrieved from http://www.foodbanknyc.org/index.cfm?objectid $=\mathrm{CD} 6 \mathrm{~F} 98 \mathrm{D} 5-\mathrm{F} 3 \mathrm{~F} 8-030 \mathrm{E}-\mathrm{B} 0 \mathrm{~A} 0 \mathrm{BB} 1 \mathrm{C} 1 \mathrm{CB} 8 \mathrm{C} 7 \mathrm{~A} 0$ \#nychungerexperience2009

Forkes, J. (2007). Nitrogen balance for the urban food metabolism of Toronto, Canada. Resources, Conservation and Recycling, 52(1), 74-94. http://dx.doi.org/10.1016/j.resconrec.2007.02.003

Friedmann, H. (2005). From colonialism to green capitalism: Social movements and emergence of food regimes. In F. Buttel \& P. McMichael (Eds.), Research in Rural Sociology and Development: New Directions in the Sociology of Global Development (Vol. 11, pp. 227-264). Greenwich, Connecticut: JAI Press Inc. http://dx.doi.org/10.1016/ S10571922(05) $\underline{11009-9}$

Hammer, J. (2004). Community food systems and planning curricula. Journal of Planning Education and Research, 23(4), 424-434 . http://dx.doi.org/ 10.1177/0739456X04264907

Hodgson, K. (2009, August-September). Where food planning and health intersect: Welcome to the next big trend. Planning, 75(8), 9-11.

Kaufman, J. (2009, Summer). Food systems planning: Moving up the planner's ladder. Plan Canada, 49(2), 12-16.

Kingsolver, B. (2007). Animal, vegetable, miracle: A year of food life. New York, New York: Harper Collins.

Lang, T., \& Heasman, M. (2004). Diet and nutrition policy: A clash of ideas or investment? Development, 47(2), 64-74. http://dx.doi.org/10.1057/palgrave. development.1100031

Larsen, K., \& Gilliland, J. (2008, April). Mapping the evolution of "food deserts" in a Canadian city: Supermarket accessibility in London, Ontario, 1961-2005. International Journal of Health Geographics, 7, 16. http://dx.doi.org/10.1186/1476-072X-7-16

MacDonald, G. (2009, November 10). Chickens come home to roost in backyards around the USA. USA Today. Retrieved from http://www.usatoday.com/ news/nation/environment/2009-11-09-urban chickens09_ST_N.htm

Magdoff, F., Buttel, F., \& Foster, J. B., (Eds.). (2000). Hungry for profit: The agribusiness threat to farmers, food and the environment. New York, New York: Monthly Review Press. 
Morison, J. I. L., Baker, N. R., Mullineaux, P. M. \& Davies, W. J. (2008). Improving water use in crop production. Philosophical Transactions of the Royal Society Biological Sciences, 363(1491), 639-658. http://dx.doi.org/10.1098/rstb.2007.2175

Nasr, J., MacRae, R., \& Kuhns, J. (2010). Scaling up urban agriculture in Toronto: Building the infrastructure.

Toronto: George Cedric Metcalf Charitable Foundation.

Nestle, M. (2002). Food politics, social policy. Pacifica, 32(4), 66.

Ontario Ministry of Agriculture, Food and Rural Affairs (OMAFRA). (2010). Agriculture land use planning staff. Retrieved 22 July 2010 from http://www.omafra.gov.on.ca/english/landuse/ facts/staff.htm

Ontario Professional Planners Institute (OPPI). (2009). Healthy communities and planning for food. Retrieved from http://www.ontarioplanners.on.ca/ content/symposium/index.aspx

Peat, D. (2010, April 27). Backyard chickens fair or fowl? Toronto Sun. Retrieved from http://www.torontosun.com/news/toronto andgta/2010/04/27/13741111.html

Pollan, M. (2006). The omnivore's dilemma: A natural history of four meals. New York, New York: Penguin Press.

Pollan, M. (2008). In defense of food: An eater's manifesto. New York, New York: Penguin Press.

Pollan, M. (2009). Food rules: An eater's manual. New York, New York: Penguin Press.

Pothukuchi, K., \& Kaufman, J. (2000). The food system: A stranger to urban planning. Journal of the American Planning Association, 66(2), 113-124. http://dx.doi. org/10.1080/01944360008976093

Power, E. (1999). Combining social justice and sustainability in food security. In M. Koc, R. MacRae, L. Mougeot, \& J. Welsh (Eds.), For hungerproof cities: Sustainable urban food systems. Ottawa: International Development Research Centre.

Qualman, D., \& Wiebe, N. (2002). The structural adjustment of Canadian agriculture. Ottawa: Canadian Centre for Policy Alternatives.
Raja, S., Born, B., \& Kozlowski Russel, J. (2008). A planners guide to community and regional rood planning: Transforming food environments, facilitating bealthy eating. Chicago, Illinois: American Planning Association.

Redwood, M. (2009). Agriculture in urban planning: Generating livelihoods and food security. Ottawa: International Development Research Council.

Schlosser, E. (2001). Fast food nation: The dark side of the all American meal. New York, New York: Houghton Mifflin.

Steel, C. (2008). Hungry city. London: Chatto \& Windus.

Trinh, L. N., Watson, J. W., Huec, N. N., Ded, N. N., Minhe, N. V., Chuf, P., Sthapit, B. R., \& Eyzaguirre, P. B. (2003). Agrobiodiversity conservation and development in Vietnamese home gardens. Agriculture, Ecosystems and Environment, 97, 317-344. http://dx.doi.org/10.1016/S01678809(02)00228-1

University of Wisconsin-Madison Department of Urban and Regional Planning. (1997). Fertile ground: Food system planning for Madison/Dane County. Final report of URPL Graduate Planning Workshop class. Department of Urban and Regional Planning, University of Wisconsin-Madison.

U.S. Census Bureau. (2010). Income, poverty and health insurance coverage in the United States: 2009. Retrieved from http://www.census.gov/prod/2010pubs/ p60-238.pdf

Watts, M., \& Goodman, D. (1997). Metabolism: Nature, culture, and industry in fin-de-siècle agro-food systems. In D. Goodman \& M. Watts (Eds.), Globalising food: Agrarian questions and global restructuring (pp. 1-32). London: Routledge.

Wittman, H. (2009). Reworking the metabolic rift: La Via Campesina, agrarian citizenship, and food sovereignty. Journal of Peasant Studies, 36(4), 805-826. http://dx.doi.org/10.1080/03066150903353991

Xuereb, M. (2005). Food miles: Environmental implications of food imports to Waterloo Region. Waterloo, Canada: Region of Waterloo Public Health. Retrieved from http://chd.region.waterloo.on.ca/en/research ResourcesPublications/resources/FoodMiles Report.pdf 